\title{
Obesity due to leptin receptor gene deficiency
}

INSERM

\section{Source}

INSERM. (1999). Orphanet: an online rare disease and orphan drug data base. Obesity due to leptin receptor gene deficiency. ORPHA:179494

A rare, genetic, non-syndromic, obesity disease characterized by severe, early-onset obesity, associated with major hyperphagia and endocrine abnormalities, resulting from leptin receptor deficiency. 